\title{
TINDAK PIDANA PORNOGRAFI MELALUI MEDIA SOSIAL INSTAGRAM BERDASARKAN PASAL 27 AYAT (1) UNDANG-UNDANG REPUBLIK INDONESIA NOMOR 19 TAHUN 2016 TENTANG INFORMASI DAN TRANSAKSI ELEKTRONIK
}

\author{
Suhartanto ${ }^{1}$, Muhammad Fahrur Rozi ${ }^{2}$ \\ 1. Dosen Program Studi Ilmu Hukum, Fakultas Hukum, Universitas Gresik \\ 2. Mahasiswa Program Studi Ilmu Hukum, Fakultas Hukum, Universitas Gresik
}

\begin{abstract}
ABSTRAK
Perkembangan teknologi juga membawa dampak negatif seperti penyalahgunaan teknologi untuk menyebarluskan pornografi yang sering disebut cyberporn. Permasalahan penelitian ini adalah: Bagaimana pertanggungjawaban pidana terhadap tindak pidana pornografi melalui media sosial instagram dan bagaimana sanksi pidana pornografi melaui media sosial instagram. Penelitian ini menggunakan pendekatan perundang-undangan, historis, konseptual dan perbandingan. Jenis sumber bahan hukum terdiri dari bahan hukum primer,bahan hukum sekunder dan bahan hukum tersier. Analisis data menggunakan analisis diskriptif kuantitatif. Hasil penelitian dan pembahasan ini menunjukkan: pengaturan hukum Indonesia telah mengatur terkait tindak pidana pornografi yang diatur dalam Undang-undang Nomor 19 Tahun 2016 tentang Informasi dan Transaksi Elektronik, sedangkan Kitab Undang-undang Hukum Pidana (KUHP), dan Undang-Undang Nomor 44 Tahun 2008 tentang Pornografi hanya untuk perbandingan.
\end{abstract}

Kata kunci: Pertanggungjawaban, Sanksi, Pidana, Cyberporn, Pornografi

\section{PENDAHULUAN}

\subsection{Latar Belakang}

Semenjak diberlakukanya KUHP, pornografi telah lebih dulu diatur sebagai tindak pidana kesusilaan, yang dimana pembagiannya terbagi menjadi dua kelompok, diantaranya kejahatan kesusilaan dan pelanggaran kesusilaan. Berikut tindak pidana yang digolongkan dalam kejahatan kesusilaan sebagaimana diatur dalam Pasal 281 sampai dengan Pasal 303 Bab XIV Buku Kedua KUHP, sedangkan tindak pidana yang digolongkan dalam pelanggaran kesusilaan berada pada Pasal 532 sampai dengan Pasal 547 Bab VI Buku Ketiga KUHP.

Definisi mengenai pornografi menjadi perdebatan sejak dirancangnya hingga dikeluarkannya Undang-Undang Nomor 44
Tahun 2008 Tentang Pornografi. Perdebatan tersebut dipicu dari ruang lingkup mengenai apa yang dimaksud dengan pornografi, sebagian berpendapat bahwa definisi pornografi dalam Undang-Undang tersebut sangat abstrak. Hal ini kemudian diluruskan oleh Mahkamah Konstitusi melalui Putusan Nomor 10-17-23/PUU-VII/2009. ${ }^{1}$

Mahkamah Konstitusi memutuskan menolak permohonan uji materiil terhadap Undang-Undang Nomor 44 Tahun 2008 tentang Pornografi karena melihat undangundang ini masih dibutuhkan untuk melindungi moralitas masyarakat. ${ }^{2}$ Adanya putusan MK diharapkan dapat menguatkan

${ }^{1}$ Dewi Bunga, 'Penanggulangan Pornografi Dalam Mewujudkan Manusia Pancasila', Jurnal Konstitusi, Vol. 8, No. 4, 2007, h. 457.

${ }^{2}$ Ibid. 
kehadiran Undang-Undang Nomor 44 Tahun 2008 Tentang Pornografi dalam mewujudkan rasa keadilan bagi rakyat Indonesia yang berbhineka dan majemuk. Hukum pada dasarnya adalah manifestasi eksternal keadilan dan keadilan adalah esensi dari roh yang merupakan perwujudan hukum. Keadilan hukum dapat dicapai jika negara dapat mengakui, melindungi dan memenuhi hak asasi warga negaranya. ${ }^{3}$

Tindak pidana pornografi sebagai salah satu bentuk norma, kaidah, atau hukum yang dirumuskan dalam perundang-undangan, baik ketentuan dalam KUHP ataupun ketentuan dalam perundang-undangan di luar KUHP, sebagaimana bentuk tindak pidana pornografi atau pornoaksi dan dalam perkembangannya menjadi tindak pidana pronografi atau pornoaksi siber (Cyberporn). ${ }^{4}$

Banyak media-media online yang sedang marak pada saat ini, khususnya media sosial instagram, tidak hanya kalangan anak muda saja yang menjadi penikmatnya tetapi orang dewasa pun turut serta mengaksesnya.

Dari sekian juta akun instagram, penulis memilih 2 akun yang menjadi contoh penelitian. Akun instagram yang mewakili adalah akun yang menayangkan pornografi, foto yang berbusana minim dan tidak pantas untuk diuanggah sebut saja mawar dengan nama akun @innesh_melan dengan jumlah follower sekitar 262 ribu akun dengan 970 unggahan (upload) yang sebagian besar bermuatan pornografi. Akun selanjutnya sebut saja melati dengan nama akun @moly_mollek yang mempunyai follower sebanyak 44 ribu

${ }^{3}$ Ibid., h. 459.

${ }^{4}$ Sudjito, et al, 'Tindak Pidana Pornografi dalam Era Siber di Indonesia', Wacana, Vol. 19, No. 2, 2016, h. 71. dengan jumlah unggahan 294 foto yang bermuatan pornografi, berbusana minim. Semakin banyak jumlah pengikut (follower), akan semakin banyak pula penikmat pornografi.

Dalam rangka menanggulangi tindak pidana pornografi (cyberporn), pemerintah indonesia sendiri telah memiliki UU ITE sebagai Cyberlaw yang berfungsi sebagai wadah untuk menekan angka tindak pidana pornografi. Sebagaimana isi dari UU ITE Pasal 27 ayat (1) dan ketentuan pidananya diatur dalam Pasal 45 ayat (1).

Pornografi sebelum keberadaan internet, sebenarnya telah menjadi permasalahan yang cukup pelik dan kompleks, ditambah lagi dengan keberadaan internet yang tentunya mempermudah akses terhadap pornografi. Berdasarkan siaran Pers Nomor 17/PIH/KOMINFO/2/2014 ditemukan bahwa penggunaan internet, khususnya media sosial sebagai tempat berbagi informasi sebesar 79,5

$\%$ khususnya anak-anak dan remaja. ${ }^{5}$

Menurut Novita dalam jurnalnya yang berjudul Budaya Hukum Cyberporn di Kota Semarang menyatakan bahwa:

Setiap detik , 3075,64 USD dibelanjakan untuk pornografi. Setiap detik, 28258 pengguna internet melihat situs pornografi. Setiap detik, 372 pengguna internet mengetik kata kunci yang berhubungan dengan pornografi di mesin pencari. Jumlah halaman situs pornografi di dunia saat ini mencapai 420 juta. Pencarian harian situs pornografi 68 juta (25\% dari total pencarian). Jumlah email pornografi perhari 2.5 miliar $(8 \%$ dari total

\footnotetext{
${ }^{5}$ Eka Nugraha Putra, Loc.Cit.
} 
email).Presentase pengguna internet yang melihat pornografi $42.7 \%$. Jumlah download bulanan konten pornografi 1.5 miliar (35\% dari total download). Total pendapatan pertahun industri pornografi di dunia adalah sekitar 97 miliar USD, ini setara dengan total pendapatan perusahaan besar di Amerika yaitu: Microsoft, Google, Amazon, eBay, Yahoo!, Apple, Netflix and EarthLink. ${ }^{6}$

Berdasarkan data diatas menunjukan bahwa pornografi membawa pengaruh terhadap menurunya nilai-nilai sosial.

Diantara KUHP dan UU ITE, terdapat beberapa kesamaan konsepsi yang bersifat multitafsir, yaitu norma kesusilaan. Rumusan mengenai "norma kesusilaan" pada dasarnya merupakan ruang terbuka yang diberikan oleh pembuat undang-undang kepada penegak hukum, khususnya Hakim, agar bisa melakukan interpretasi sosiologis yang tepat berdasarkan living law dalam masyarakat yang pluralistik.

Meskipun demikian, upaya pemerintah untuk menekan angka pornografi dalam UU ITE ini patut diberi apresiasi. Walaupun dalam praktiknya, banyak sekali protes dan kecaman dari beberapa komunitas pengakses internet. Jika dibaca sekilas tanpa memahami dulu lebih dalam, UU ITE ini terkesan hanya sebagai penyelamat bagi keamanan transaksi elektronik semata, seperti yang selama ini banyak disiarkan media. UU ITE ini telah jauh melenceng dari misi awalnya.

Untuk mencapai tujuan bersama berupa keinginan untuk menekan angka pornografi melalui media sosial instagram, maka harus

${ }^{6}$ Novita, 'Budaya Hukum Cyberporn Di Kota Semarang', Pandecta, Vol. 7, No. 2, 2012, h. 186. ada kompromi di antara masyarakat dan pemerintah. Komitmen suatu negara untuk memberantas pornografi tergantung pada politik hukum dan kondisi negara yang bersangkutan, hal ini sesuai dengan Konggres PBB Ke V Tahun 1975 di Geneva, Swiss yang menyatakan bahwa dikriminalisasikan atau tindak pornografi atau kejahatan di bidang kesusilaan ini dihubungkan dengan kuat dan lemahnya hubungan antara moral dan hukum (law and moral standard) di negara yang bersangkutan. ${ }^{7}$

Dengan demikian, pengaturan tindak pidana pornografi dalam upaya penanggulangan pornografi era siber di Indonesia diperlukan adanya suatu keharusan, bahwa pengaturan tindak pidana pornografi atau pornoaksi siber di Indonesia senantiasa memenuhi keberlakuan hukum secara filosofis, sosiologis, dan yuridis terkait dengan dinamika ilmu pengetahuan dan teknologi, terutama teknologi informasi dan komunikasi dengan berbagai dampak positif atau negatif yang mungkin muncul di masa masa mendatang. ${ }^{8}$

\subsection{Rumusan Masalah}

Dari berbagai latar belakang diatas munculah rumusan masalah sebagai berikut :

1. Bagaimana pertanggungjawaban pidana pornografi melalui media sosial instagram berdasarkan Pasal 27 Ayat (1) UndangUndang Nomor 19 Tahun 2016 Tentang Informasi dan Transaksi Elektronik ?

2. Bagaimana sanksi pidana terhadap pelaku pornografi melalui media sosial instagram

${ }^{7}$ Enik Isnaini, 'Penanggulangan Tindak Pidana Pornografi Dalam Media Internet', Jurnal Independent, Vol. 2, No. 2, h. 25.

${ }^{8}$ Bambang Sudjito, et al, Op.Cit, h. 71 . 
berdasarkan Pasal 27 Ayat (1) UndangUndang Nomor 19 Tahun 2016 Tentang Informasi dan Transaksi Elektronik Pada saat ini ?

\subsection{Tujuan Penelitian}

Sehubungan dengan rumusan masalah tersebut maka tujuan penelitian dalam skipsi ini adalah sebagai berikut :

1. Untuk mengetahui, memahami dan menganalisis tentang pertanggungjawaban pidana terhadap pelanggaran atau kejahatan kesusilaan khususnya dibidang pornografi melalui media sosial instagram yang ditinjau dari Pasal 27 Ayat (1) Undang-Undang Republik Indonesia Nomor 19 Tahun 2016 Tentang Informasi dan Transaksi Elektronik.

2. Untuk mengetahui, memahami dan menganalisis mengenai sanksi pidana terhadap pelanggaran atau kejahatan kesusilaan khususnya dibidang pornografi melalui media sosial instagram menurut Pasal 27 Ayat (1) Undang-Undang Republik Indonesia Nomor 19 Tahun 2016 Tentang Informasi Dan Transaksi Elektronik.

\subsection{Manfaat Penelitian}

Manfaat dari segi teoritis, hasil penelitian ini diharapkan dapat bermanfaat bagi akademisi hukum pidana dan dapat memberi bantuan pemikiran dan konsep dalam mengembangkan ilmu pengetahuan dalam hukum pidana, khususnya mengenai pertanggungjawaban tindak pidana pornografiatau cyberporn melalui media sosial instagram.
Manfaat dari segi praktis, hasil penelitian yang berfokus pada penulisan ini diharapkan bisa menjadi bahan pertimbangan dan sumbangan pemikiran, serta dapat memberikan kontribusi dan solusi kongkrit bagi para legislator dalam memberikan sanksi pidana terhadap pelaku pornografi melalui media sosial instagram serta upaya penanggulangan pornografi (cyberporn) di Indonesia. Dengan pendekatan kebijakan hukum pidana yang tetap memperhatikan pendekatan aspek lainnya dalam kesatuan pendekatan sistemik dan integral, diharapkan dapat menghasilkan suatu kebijakan formulasi yang dapat menjangkau lebih dalam terhadap kejahatan didunia maya ini, khususnya dalam rangka pembaharuan hukum pidana Indonesia dimasa yang akan datang.

\section{TINJAUAN PUSTAKA}

\subsection{Kesalahan Dan Konsep Pertanggungjawaban Pidana}

Pandangan ahli pada umumnya memiliki pendapat bahwa hukum pidana dalam memandang kesalahan merupakan unsur yang sangat fundamental dalam menentukan pertanggungjawaban pidana. Penilaian adanya kesalahan dalam hukum pidana dapat menentukan ada atau tidak adanya pertanggungjawaban pidana. Pemikiran ini erat kaitanya dengan asas tiada pidana tanpa kesalahan atau bisa disebut dengan istilah geen straf zonder schuld, atau actus non facit reum nisi mens sit rea, dan an act does not make a person guilty unless his mind is guilty.

Seorang filosof besar abab ke-20, Rosceo Pound menyatakan bahwa "Pertanggungjawaban pidana diartikan sebagai suatu kewajiban untuk membayar 
pembalasan yang akan diterima pelaku dari seorang yang telah dirugikan," menurutnya juga bahwa "Pertanggungjaawaban yang dilakukan tersebut tidak hanya menyangkut masalah hukum semata akan tetapi menyangkut pula masalah nilai-nilai moral ataupun nilai kesusilaan yang ada dalam masyarakat.

Secara umum negara civil law maupun common law merumuskan pertanggungjawaban pidana itu negatif. Dalam hal ini berarti hukum pidana di Indonesia, memandang Undang-Undang justru merumuskan keadaan-keadaan yang dapat menyebabkan pembuat tidak dipidana (strafuitsluitingsgronden), yang untuk sebagian adalah alasan untuk penghapus kesalahan. Sedangkan dalam praktik peradilan di negara-negara common law, diterima berbagai alasan umum pembelaan (general defence) atau alasan umum peniadaan pertanggungjawaban (general excusing of liability). ${ }^{9}$

Perumusan pertanggungjawaban pidana secara negatif dapat dilihat dalam ketentuan Pasal 44, 48, 49, 50 dan 51 KUHP yang keseluruhanya merumuskan hal-hal yang dapat mengecualikan pembuat dari pengenaan pidana. Pengecualian pengenaan pidana disini dapat dibaca sebagai pengecualian adanya pertanggungjawaban pidana. Dalam hal tertentu dapat berarti pengecualian adanya kesalahan.

Pertanggungjawaban pidana dipandang ada, kecuali ada alasan-alasan penghapus pidana tersebut. Dengan kata lain, criminal liability dapat dilakukan sepanjang pembuat tidak memiliki 'defence', ketika melakukan suatu tindak pidana. Dalam lapangan acara pidana, hal ini berarti seorang terdakwa dipandang bertanggungjawab atas tindak pidana yang dilakukannya, jika tidak dapat membuktikan bahwa dirinya mempunyai 'defence' ketika melakukan tindak pidana itu. Konsep demikian itu membentuk keseimbangan antara hak mendakwa dan menuntut dari penuntut umum, dan hak menyangkal mengajukan pembelaan dari terdakwa. ${ }^{10}$

Pertanggungjawaban sesorang dalam hukum pidana berarti dipidana, dengan begitu konsep pertanggungjawaban pidana merupakan syarat-syarat yang diperlukan untuk mengenakan pidana terhadap seorang pembuat tindak pidana.

\subsection{Arti Dan Tujuan Pidana}

Beberapa di antara para ahli hukum pidana menyadari betul persoalan pemidanaan bukanlah sekadar masalah tentang proses sederhana memidana seseorang dengan menjebloskannya ke penjara. Refleksi yang paling kecil saja, dengan mudah menunjukkan bahwa memidana sesungguhnya mencakup pula pencabutan (peniadaan), termasuk proses pengadilan itu sendiri. Maka kesepakatan tentang apa pemidanaan itu merupakan hal yang penting sebelum menempatkan perintah (putusan) ke berbagai aplikasi paksaan publik pada individu, entah atas nama kesehatan, pendidikan, ataupun kesejahteraan umum. ${ }^{11}$

\footnotetext{
${ }^{10}$ Ibid, h. 64.

${ }^{11}$ Sholehuddin, Sistem Sanksi Dalam Hukum Pidana, Ed. 1-3, Raja Grafindo Persada, Jakarta, 2007, h. 69.
}

${ }^{9}$ Chairul Huda, Dari 'Tiada Pidana Tanpa Kesalahan' Menuju Kepada 'Tiada Pertanggungjawaban Pidana Tanpa Kesalahan', Prenadamedia Group, Cet. 6, Jakarta, 2015, h. 63. 
Ted Honderich ${ }^{12}$ berpendapat bahwa pemidanaan harus memuat tiga unsur. Pertama, pemidanaan harus mengandung semacam kehilangan (deprivation) atau kesengsaraan (distress) yang biasanya secara wajar dirumuskan sebagai sasaran dari tindakan pemidanaan. Kedua, setiap pemidanaan harus datang dari institusi yang berwenang secara hukum pula. Jadi, pemidanaan tidak merupakan konsekuensi alamiah suatu tindakan. Ketiga, penguasa yang berwenang berhak untuk menjatuhkan pemidanaan hanya kepada subjek yang telah terbukti secara sengaja melanggar hukum atau peraturan yang berlaku dalam masyarakatnya. Meskipun demikian, secara umum pemidanaan dapat dirumuskan terbuka sebagai denda (penalty) yang diberikan oleh instansi yang berwenang kepada pelanggar hukum atau peraturan.

Kongres PBB tahun 1984 di Venezuela membahas tentang pencegahan dilakukannya kejahatan, antara lain dinyatakan bahwa narapidana yang dijatuhi hukuman penjara seumur hidup adalah tidak sesuai dengan salah satu tujuan utama dari pemidanaan, yaitu reintegrasi terhukum ke dalam masyarakat. Sehingga pada akhir kongres melahirkan poin yang menyatakan:

Sementara akibat-akibat dari "pemenjaraan" bagi narapidana yang dijatuhi hukuman penjara seumur hidup mungkin sesuaiuntuk administrasi pidana dalam waktu singkat, narapidana yangdiinstitusionalisasi cenderung untuk menciptakan persoalan penangananyang lebih sedikit dibanding dengan orang yang

${ }^{12}$ Ibid., h. 70 . tidak mengalami prosesinstitusionalisasi. Akibat-akibat ini paling tidak sesuai dengan salah satutujuan utama dari pemidanaan; reintegrasi terhukum ke dalam masyarakat, institusionalisasi mengantarkan narapidana dengan perlengkapanburuk itu kepada suatu pengalaman dan interaksi dengan dunia di luarpenjara. ${ }^{13}$

Mengenai lamanya hukuman yang diberikan kepada narapidana tidak akan menjamin bahwa narapidana tersebut akan baik setelah keluar nantinya, sehingga tidak menjamin akan berkurangnya kejahatan massa.

Di samping itu juga adanya perkembangan pemikiran mengenai teori pemidanaan mengakibatkan para sarjana berpikir untuk merumuskan tujuan pemidanaan yang ideal. Dengan adanya kritik-kritik mengenai dasar pemidanaan yang menyangkut hubungan antara teori pidana, pelaksanaan pidana dan tujuan yang hendak dicapai serta hasil yang diperoleh dari penerapan pidana. Kritikan tersebut sangat berpengaruh besar terhadap proses pembuatan Rancangan Kitab Undangundang Hukum Pidana Nasional yang telah rampung tahun 2000 yang lalu dan telah disosialisasikan sejak bulan Desember tahun $2000 .{ }^{14}$ Konsep KUHP nasional tersebut telah mengalami beberapa perubahan mulai dari konsep tahun 1971/1972, konsep KUHP 1982/1983, konsep KUHP 1993 dan terakhir konsep KUHP Nasional tahun 2009.

\footnotetext{
${ }^{13}$ Ibid., h. 15-16, dikutip dari United Nations, Life Imprisonsment Crime Prevention And Criminal Juctice, Brance, Vienna, 1994, h. 7.

${ }^{14}$ Ibid., h. 25.
} 


\section{METODE PENELITIAN}

Penelitian yang dilakukan untuk penulisan ini adalah penelitian hukum normatif (normative legal research), bisa juga disebut sebagai penelitian hukum doktrinal. Pada penelitian ini, sering kali hukum dikonsepsikan sebagai apa yang tertulis dalam Peraturan Perundang-Undangan ( Law in book ) atau hukum yang dikonsepsikan sebagai kaidah atau norma yang merupakan patokan berperilaku masyarakat terhadap apa yang dianggap pantas. Namun sesungguhnya hukum juga dapat dikonsepkan sebagai apa yang ada dalam tindakan ( Law in action). Law in book adalah hukum yang seharusnya berjalan sesuai harapan, keduanya seiring berbeda, artinya hukum dalam buku sering berbeda dengan hukum dalam kehidupan masyarakat. ${ }^{15}$ Dalam Penelitian hukum normatif ini penelitian hukum yang dilakukan dengan cara mempelajari permasalahan dilihat dari segi aturan hukum tentang tindak pidana pornografi melalui media sosial instagram.

Sumber bahan hukum dalam penulisan ini antara lain bahan hukum primer yang terdiri dari buku-buku teks dan perundang-undangan. Kemudian bahan hukum sekunder seperti jurnal-jurnal hukum, dan kamus-kamus hukum, dan yang terakhir menggunakan bahan hukum tersier sebagai penunjang seperti media online (daring) dan lain-lain.

\subsection{Pendekatan Masalah}

Sedangkan pendekatan penelitian atau metode cara mengadakan penelitian menggunakan 3 jenis yaitu: Pendekatan

15"Penelitian Hukum Normatif", http://www.informasipendidikan.com/2013/08/penelitian-hukum-normatif.html, diuanggah 28 agustus 2017, diakses pada tanggal 16 maret 2018 .
Konseptual (Conceptual Approach), Pendekatan Perundang-Undangan (Statue Aprroach) yaitu dalam metode pendekatan Perundang-Undangan peniliti perlu memahami hierarki, dan asas dalam perturan Perundang-Undangan. ${ }^{16}$ Pendekatan Historis (Historical Aprroach)' Pendekatan Perbandingan (Comparative Approach)

\subsection{Teknik Pengumpulan Bahan Hukum}

Teknik pengumpulan bahan hukum dalam penelitian ini adalah dengan cara studi kepustakaan, yaitu mengumpulkan serta meneliti bahan pustaka yang terdiri dari bahan hukum primer berupa buku-buku teks, dan peraturan perundang-undangan, bahan hukum sekunder yang berupa artikel, internet dan bahan hukum tersier yang berupa kamus, ensiklopedia yang terkait dengan tindak pidana pornografi di Indonesia.

Metode yang digunakan dalam pengolahan maupun dalam analisis data yang digunakan dalam penelitian ini adalah kuantitatif, memusatkan perhatian pada prinsip-prinsip umum yang mendasari perwujudan satu gejala yang ada dalam kehidupan manusia, atau polapola yang dianalisis gejala-gejala sosial budaya dengan menggunakan kebudayaan dari masyarakat yang bersangkutan untuk memperoleh gambaran mengenai pola-pola yang berlaku.

Analisa preskriptif adalah analisis yang berdasarkan pada tujuan hukum, nilai-nilai keadilan, validitas aturan hukum, konsepkonsep hukum dan norma-norma hukum yang dimaksudkan untuk menemukan jawaban atas

\footnotetext{
${ }^{16}$ Peter Mahmud Marzuki, Penelitian Hukum,
} prenadamedia group, Jakarta, 2016, h 136. 
permasalahan yang disajikan dalam bentuk penelitian.

\section{HASIL PENELITIAN DAN PEMBAHASAN}

\subsection{Pertanggungjawaban Pidana}

Pornografi Melalui Media Sosial

Instagram Berdasarkan Pasal 27

Ayat (1) Undang-Undang Nomor 19

Tahun 2016 Tentang Informasi Dan

\section{Transaksi Elektronik}

Apabila tindak pidana dalam Pasal 27 Ayat

(1) dan ancaman pidananya dalam Pasal 45

Avat (1) disalin dalam satu naskah, maka bunyi selengkapnya adalah:

Setiap orang dengan sengaja dan tanpa hak mendistribusikan dan/atau mentransmisikan dan/atau membuat dapat diaksesnya Informasi Elektronik dan/atau Dokumen Elektronik yang memiliki muatan yang melanggar kesusilaan dipidana dengan pidana penjara paling lama 6 (enam) tahun dan/atau denda paling banyak Rp 1.000.000.000,00 (satu miliar rupiah).

Apabila dilihat dari sudut teknis dan formulasi rumusannya, akun atas nama @innesh_melan dan@moly_mollek merupakan tindak pidana di bidang "informasi dan transaksi elektronik". Karena objek perbuatan yang sekaligus objek tindak pidananya berupa Informasi Elektronik dan atau Dokumen Eletronik. Sementara jika dilihat dari sudut letak atau tempat sifat larangannya (melawan hukum), atau dari sudut kepentingan hukum yang hendak dilindungi, dapat dikelompokkan ke dalam tindak pidana kesusilaan khususnya dibidang pornografi. Perbuatan mendistribusikan, mentransmisikan dan atau membuat dapat diaksesnya Informasi Elektronik dan atau Dokumen Elektronik baru dapat dipidana, atau timbul sifat melawan hukumnya, apabila isi informasi dan atau Dokumen Elektronik tersebut mengandung muatan yang melanggar kesusilaan.

Kepentingan hukum yang hendak dilindungi oleh Pasal27 Ayat (1), adalah kepentingan hukum mengenai tegak dan terjaganya nilai-nila kesusilaan masyarakat baik konvensional maupun elektronik. Tindak pidana pokoknya adalah kesusilaan, sementara sarananya dengan memanfaatkan atau menggunakan sistem jaringan teknologi ITE. Dari alasan terakhir inilah, maka tindak pidana Pasal 27 Ayat (1) juncto Pasal 45 Ayat (1) dapat disebut lex specialis dari bentuk bentuk tindak pidana kesusilaan dalam Bab XIV BukuII KUHP.

Tindak pidana Pasal 27 Ayat (1) apabila dirinci terdiri dari beberapa unsur anatara lain: unsur subjektif, kesalahan (dengan sengaja), unsur objektif melawan hukum (tanpa hak), perbuatanya (mendistribusikan, mentransmisikan dan membuat dapat diaksesnya), serta objeknya (informasi elektronik, dokumen elektronik yang memiliki muatan yang melanggar kesusilaan). ${ }^{17}$ Frasa yang dicetak miring merupakan unsur formil yang membentuk tindak pidana tersebut.

Berdasarkan logika yang diterangkan Memorie van Toelichting, maka tidaklah setiap perbuatan mentransmisikan Informasi Elektronik yang isinya melanggar kesusilaan, bersifat melawan hukum. Benarkah demikian, Jawaban singkatnya tentu tidaklah demikian.

${ }^{17}$ Adami Chazawi Dan Ardi Ferdian,Tindak Pidana Informasi \& Transaksi Elektronik, Cet. 1, Edisi Revisi, Media Nusa Creative, Malang, 2015, h. 11. 
Bukan keterangan $M v T$ yang salah, tetapi mencantumkan unsur melawan hukum dalam rumusan Pasal 27 Ayat (1) yang tidak tepat. Berdasarkan sifat dan isi informasi yang memuat pelanggaran kesusilaan, dari sudut objektif maka sifat melawan hukumnya perbuatan terletak pada isi Informasi Elektronik yang melanggar kesusilaan. Rasanya tidak ada perbuatan mentransmisikan Informasi Elektronik atau data elektronik yang memuat pelanggaran kesusilaan melawan hukum.

Penempatan atau unsur-unsur "tanpa hak" dalam Pasal 27 ayat (1), hubunganya yang paling dekat, secara objektif pada objek tindak pidananya. Si pembuat atau pemilik akun baik @innesh_melan maupun@molly_molek tidak berhak melakukan perbuatan mentransmisikan Infomasi Elektronik, adalah terletak pada informasi tersebut yang melanggar kesusilaan. Dan secara subjektif pada kesengajaan si pembuat. Hubungan unsur "tanpa hak" lebih dekat dengan unsur "dengan sengaja", unsur sengaja diletakan sebelum unsur "tanpa hak" dalam struktur rumusan tindak pidana. Berdasarkan keterangan $M v T$, maka tidak diragukan lagi bahwa sengaja ditujukan atau meliputi unsur tanpa hak.

Terdapat 3 unsur perbuatan yang dilarang dalam Pasal 27 Ayat (1) UU ITE. Mekipun antara tiga perbuatan itu dipisahkan dengan frasa "dan/atau", tidaklah berarti tiga perbuatan tersebut mempunyai arti yang sama. Logika pencantuman perkataan "dan/atau", bahwa antara tiga tingkah laku tersebut bisa terjadi serentak dalam suatu peristiwa. Bisa juga terjadi salah satu saja. Bila suatu unsur tidak diberikan penjelasan, baik dalam Pasal 1, penjelasan umum maupun penjelasan pasalnya, pertama harus ditafsirkan berdasarkan bahasa (gramatikal). Jika menurut bahasa tidak didapat hal yang sesuai, barulah melihat apa maksud pembentuk Undang-Undang. Bila juga tidak ditemukan, barulah menggunakan cara-cara menafsirkan yang lain. ${ }^{18}$

Terdapat dua objek perbuatan yang sekaligus objek tindak pidana, ialah "Informasi Elektronik" dan "Dokumen Elektronik". Antara dua frasa tersebut dipisahkan dengan kata "dan/atau" mengandung arti, bahwa dalam suatu peristiwa ada satu objek saja, dan bisa jadi pula pada kedua objek. Sementara frasa "yang memiliki muatan yang melanggar kesusilaan" adalah merupakan unsur "keadaan yang menyertai" yang melekat pada objek tindak pidana tersebut. Pada keadaan inilah letak sifat melawan hukumnya perbuatan-perbuatan yang dilarang dalam tindak pidana Pasal 27 Ayat (1). ${ }^{19}$

Mengenai bentuk-bentuk tindak pidana kesusilaan, sebagai kejahatan ditempatkan dalam Pasal 281 sampai dengan Pasal 303 Bab XIV Buku Kedua KUHP. Sementara dalam bentuk pelanggaran ditempatkan pada pasal 532 sampai dengan Pasal 547 Bab VI Buku Ketiga KUHP. Begitu banyak jenis-jenis kejahatan maupun pelanggaran kesusilaan. Dalam praktik bisa menjadi persoalan yang serius, disebabkan Pertama, karena dalam pasal-pasal tersebut tidak ada keterangan sedikitpun tentang arti kesusilaan (zeden). Kedua, begitu banyak tindak pidana kesusilaanbaik jenis kejahatan maupun pelanggaran. Ancaman pidananya yang sangat

\footnotetext{
${ }^{18}$ Ibid., h. 28.

${ }^{19}$ Ibid., h. 32.
} 
beragam,mulai yang terendah pidana kurungan tiga hari ${ }^{20}$ sampai pidana 12 tahun $^{21}$ yang bisa diperberat menjadi 15 tahun. ${ }^{22}$ Oleh sebab diatas maka dalam hal untuk mencari arti unsur "yang memiliki muatan yang melanggar kesusilaan" dapat menimbulkan beberapa pendadapat.

Untuk menerapkan pengertian "yang memiliki muatan yang melanggar kesusilaan" harus melihat pada bentuk-bentuk tindak pidana kesusilaan yang ada di dalam KUHP. Alasannya ialah, bahwa tindak pidana Pasal 27 Ayat (1) UU ITE adalah tindak pidana kesusilaan khusus (lex sepecialis) dari bentukbentuk tindak pidana kesusilaan yang ada di dalam KUHP Suatu jenis tindak pidana kesusilaan dengan menggunakan sarana teknologi elektronik. Kekhususannya terletak pada sarana yang digunakan. Karena istilah "kesusilaan" dalam frasa "yang memiliki muatan yang melanggar kesusilaan" dalam Pasal 27 Ayat (1) tidak di jelaskan dalam UU ITE. Sementara di dalam KUHP istilah kesusilaan (zeden) baik dalam Buku II Bab XIV (Misdrijven tegende zeden) maupun Buku III Bab VI (Overtredingen betreffende de zeden), juga tidak dijelaskan. Oleh karena dalam KUHP tidak diberikan keterangan tentang arti kesusilaan tersebut. Maka untuk menerapkan Pasal 27 Ayat (1) UU ITE, dengan menyesuaikan dengan tindak pidana kesusilaan yang mana yang telah dilakukan si pembuat (terdakwa) pemilik akun diatas yang bersesuaian dengan pasal-pasal yang ada dalam Bab XIV Buku II maupun Bab VI Buku III KUHP.

${ }^{20}$ Lihat Pasal 532 KUHP.

${ }^{21}$ Lihat Pasal 285 KUHP.

${ }^{22}$ Lihat Pasal 291 KUHP.
Dengan mendasarkan pada Pasal 281 angka 1 KUHP. Dalam Pasal 281 angka 1 frasa "openbaar de eerbaarheid schendt"23 oleh banyak pakar hukum pidana diterjemahkan dengan "terbuka melanggar kesusilaan". Frasa "eerbaarheid schendt" diterjemahkan dengan "melanggar kesusilaan", yang sama digunakan dalam Pasal 281 angka 1 KUHP. Apa salahnya menerapkan Pasal 27 Ayat (1) sebagai lex specialis dengan merujuk atau menggunakan Pasal 281 angkal KUHP sebagai dasar lex generalisnya.

Dengan dapat timbulnya berbagai tafsir terhadap satu norma hukum, sebagai indikator adanya kesalahan dalam perumusannya. Demikian juga kiranya mengenai rumusan ayat (1) (termasuk ayat-ayat lainnya) dari Pasal 27 UU ITE ini. Kiranya kelemahan perumusannya ini dapat diatasi dengan yurisprudensi Mahkamah Agung.

\subsection{Sanksi Pidana Terhadap Pelaku Pornografi Melalui Media Sosial Instagram Berdasarkan Pasal 27 Ayat (1) Undang-Undang Nomor 19 Tahun 2016 Tentang Informasi Dan Transaksi Elektronik}

Salah satu ketentuan yang mengatur tentang pornografi dalam delik kesusilaan, yaitu dalam Pasal 282 KUHP. Rumusan unsur-unsur tindak pidana dalam Pasal 282 ini dapat digunakan untuk menjerat tindak pidana cyberporn, yaitu sebagai berikut:

a) Menyiarkan;

b) Mempertunjukan atau menempelkan di muka umum, tulisan, gambaranatau

${ }^{23} I b i d .$, h. 51. 
benda, yang telah diketahui isinya dan yang melanggar kesusilaan;

c) Memasukannya ke dalam negeri, meneruskannya, mengeluarkannya keluar negeri; atau

d) Mempunyainya dalam persediaan;

e) Menjadikan hal tersebut sebagai pencarian atau kebiasaan. ${ }^{24}$

Kesulitan dalam mengatasi tindak pidana pornografi antara lain disebabkan oleh adanya pengertian dan penafsiran yang berbeda-beda terhadap pasal-pasal KUHP yang mengatur masalah pornografi, dan dahulu masyarakat lemah dalam merespon pornografi. ${ }^{25}$

Jenis sanksi pidana (strafsoort) yang dirumuskan dalam delik kesusilaan di KUHP adalah pidana pokok, terdiri dari pidana penjara, kurungan, dan denda. Lamanya ancaman pidana penjara dalam kejahatan kesusilaan antara 4 (empat) bulan sampai dengan 12 (dua belas) tahun, sedangkan pidana dendanya antara Rp 4.500,00 (empat ribu lima ratus rupiah) sampai dengan Rp 75.000,00 (tujuh puluh lima ribu rupiah). Sementara untuk pelanggaran kesusilaan, lamanya ancaman pidana kurungan antara 3 (tiga) hari sampai dengan 3 (tiga) bulan dan pidana dendanya antara $\operatorname{Rp} 255,00$ (dua ratus dua puluh lima rupiah) sampai dengan $\mathrm{Rp}$ 4.500,00 (empat ribu lima ratus rupiah).

Sementara ketentuan pidana dalam UUP diatur dalam Bab VII Pasal 29 sampai dengan Pasal 38. Pada dasarnya beberapa ketentuan pidana dalam undang-undang ini dapat digunakan untuk menjerat pelaku cyberporn, khususnya pada menyiarkan,

${ }^{24}$ Lihat ketentuan Pasal 282 KUHP.

${ }^{25}$ Neng Djubaedah, Pornografi dan Pornoaksi Ditinjau dari Hukum Islam, Kencana, Jakarta, 2003, h. 128. mempertontonkan, mempertunjukan atau menjadi model pornografi yang dilakukan melalui media sosial Instagram, seperti Pasal 29, Pasal 30, Pasal 34, Pasal 36, dengan unsur perbuatannya sebagai berikut:

a) Pasal 29: memproduksi, membuat, memperbanyak, menggandakan, menyebarluaskan, menyiarkan, mengimpor, mengekspor, menawarkan, memperjualbelikan, menyewakan, atau menyediakan pornografi;

b) Pasal 30: menyediakan jasa pornografi;

c) Pasal 34: menjadi objek atau model yang mengandung muatanpornografi;

d) Pasal 36: mempertontonkan diri atau orang lain dalam pertunjukan ataudi muka umum yang menggambarkan ketelanjangan, eksploitasiseksual, persenggamaan, atau yang bermuatan pornografi;

Undang-Undang Pornografi tidak memberikan penjelasan secara rinci tentang bagaimana cara menyiarkan, mempertontonkan, maupun menyalahgunakan internet untuk penyebaran pornografi, namun berdasarkan pengertian pornografi yang menyatakan media atau sarananya adalah “...melalui berbagai bentuk media komunikasi dan/atau pertunjukan di muka umum...,", maka menurut penulis internet khususnya media sosial Instagram merupakan media komunikasi yang dapat digunakan untuk penyebaran foto maupun video pornografi.

Sistem perumusan jumlah atau lamanya pidana dalam Undang-undang Pornografi adalah minimum khusus dan maksimum khusus, yaitu: (1) untuk pidana penjara: miminum khusus antara 6 bulan sampai

${ }^{26}$ Lihat Pasal 1 angka 1UUP. 
dengan 2 tahun, dan maksimum khusus antara 6 tahun sampai dengan 15 tahun; (2) untuk pidana denda: minimum khusus antara $\mathrm{Rp}$ 250.000.000,00 (dua ratus lima puluhjuta rupiah) sampai dengan Rp 1.000.000.000,00 (satu miliar rupiah), dan maksimum khusus antara Rp 3.000.000.000 (tiga miliar rupiah) samapi dengan Rp 7.500.000.000,00 (tujuh miliar lima ratus juta rupiah) Sementara dalam ketentuan Pasal 31, Pasal 32, Pasal 34 dan Pasal 36 Undang-undang Pornografi menggunakan rumusan pidana maksimum khusus, yaitu: (1) maksimum khusus untuk pidana penjara antara 4 tahun sampai dengan 10 tahun; (2) maksimum khusus untuk pidana denda antara Rp 2.000.000.000,00 (dua miliar rupiah) sampai dengan $\mathrm{Rp}$ 5.000.000.00,00 (lima miliar rupiah).

Adanya indikasi konten cyberporn pada Instagram, yang paling sering adalah mengunggah dengan pakaian yang menggoda, semisal hanya menggunakan celana pendek, tank top, dan pakaian lain yang berpotensi mengumbar aurat dan bagian pribadi dari si pengunggah seperti pemilik akun atas nama @innesh_melandan@molly_molek.

Berdasarkan pemaparan diatas, maka bisa dikatakan bahwa pengguna media sosial Instagram telah melanggar pasal 27 ayat 1 Undang-Undang Republik Indonesia Nomor 19 Tahun 2016 Tentang Informasi dan Transaksi Elektronik yang berbunyi: "Setiap Orang dengan sengaja dan tanpa hak mendistribusikan dan/atau mentransmisikan dan/atau membuat dapat diaksesnya Informasi Elektronik dan/atau Dokumen Elektronik yang memiliki muatan yang melanggar kesusilaan." Dengan konsep analisa sebagai berikut : a) Setiap orang disini adalah ditunjukan kepada bahwa pengguna media sosial Instagram atau disebut dengan pemilik akun yang mengandung konten nudity dan mengarah pada pelanggaran kesusilaan saat mengunggah foto ataupun video berdurasi pendek.

b) Dengan sengaja yang dapat diartikan bentuk kesengajaan pemilik akun atas nama@innesh_melandan@molly_molek telah terbukti melakukan dalam hal melaksanakan delik yang diancamkan dalam pasal tersebut.

c) Tanpa hak, disini tanpa hak diartikan sebagai melawan hukum yaitu tanpa adanya hak sendiri (zonder eigen recht), bertentagan dengan hukum pada umumnya (in strijd met het recht in het algemeen), bertentangan dengan hak pribadi seseorang (in strijd met een anders subjectieve recht), bertentangan dengan hukum objektif (tegen het objectieve recht), semua unsur pornografi dalam pengguna media sosial Instagram merupakan tindakan yang melawan hukum dan bertentangan dengan hak pribadi seseorang karena mereka telah mempertontonkan hal negatif dalam media massa yang sifatnya umum.

d) Arti mendistribusikan disini adalah bahwa pemilik akun diatas saat mengunggah foto maupun video, mereka menyalurkan (membagikan, mengirimkan) konten yang mengandung unsur kesusilaan kepada pengguna lain yang menikmatinya.

e) Arti dari mentransmisikan yaitu mengirimkan atau meneruskan pesan dari pemilik akun kepada pengguna akun lain saat mengunggah. 
f) Membuat dapat diaksesnya konten pornografi yaitu semua pemilik akun Instagram akan dengan mudah mengakses dan mengoperasikan unggahanya yang mengandung konten pornografi, hal ini merupakan tindakan yang dapat dikenakan pidana oleh pasal 27 ayat 1 UU ITE.

g) Informasi elektronik adalah satu atau sekumpulan data elektronik diantaranya meliputi teks, simbol, gambar, tanda-tanda, isyarat, tulisan, suara, bunyi, dan bentukbentuk lainnya yang telah diolah sehingga mempunyai arti atau dapat dipahami oleh orang yang mampu memahaminya, dalam pasal ini informasi elektronik yang dimaksud adalah memiliki muatan yang melanggar kesusilaan seperti yang ada pada Instagram.

h) Arti dokumen elektronik adalah setiap Informasi Elektronik yang dibuat, diteruskan, dikirimkan, diterima, atau disimpan dalam bentuk analog, digital, elektromagnetik, optikal, atau sejenisnya, yang dapat dilihat, ditampilkan, dan/atau didengar melalui Komputer atau Sistem Elektronik, tetapi tidak terbatas pada tulisan, suara, gambar, peta, rancangan, foto atau sejenisnya, huruf, tanda, angka, Kode Akses, simbol atau perforasi yang memiliki makna atau arti atau dapat dipahami oleh orang yang mampu memahaminya yang dimuat dengan melanggar kesusilaan yang ditampilkan dalam media sosial Instagram.

i) Memiliki muatan melanggar kesusilaan. Yaitu para pengguna di aplikasi Instagram berlomba-lomba memberikan konten foto maupun video yang berpotensi mendapatkan jumlah pengikut (follower).
Yang paling sering adalah konten dengan pakaian yang menggoda. Misalnya hanya menggunakan celana pendek, dan pakaian lain yang berpotensi mengumbar aurat dan bagian pribadi dari si pemilik akun. Pakaian yang menggoda itu biasanya diiringi oleh aktivitas yang dilakukan pemilik akun dalam akunya. Seperti menari, dari yang biasa sampai menjurus kearah striptis hingga melakukan adegan asusila dengan lawan jenis seperti berciuman.

Sanksi pidana pasal 27 ayat (1) terdapat pada pasal 45 ayat (1) yaitu hukuman pidana penjara paling lama 6 (enam) tahun dan/atau denda paling banyak Rp. 1.000.000.000,00 (satu miliar rupiah).Yang dapat dijerat oleh ketentuan Pasal 27 ayat 1 UU ITE ini adalah pihak yang mendistribusikannya, mentransmisikan dan/atau membuat dapat diaksesnya Informasi elektronik dan/atau dokumen elektronik yang mempunyai muatan melanggar kesusilaan, sedangkan untuk produsen dan pemilik perangkat lunak dan perangkat keras dalam hal program muatan pornografi seperti perusahaan Instagram tidak dijerat dengan pasal ini tetapi dikenakan dengan pasal 34 ayat (1) dan dikenakan sanksi pidana sebagaimana ditentukan dalam Pasal 50 UU ITE dan Transaksi Elektronik. Dimana ancaman pidananya lebih berat daripada pasal 45 yang diperuntukan untuk distributor yaitu pidana penjara paling lama 10 tahun dan/atau denda paling banyak Rp.10.000.000.000,00 (sepuluh miliar rupiah). 


\section{PENUTUP}

\subsection{Kesimpulan}

Dari hasil pembahasan yang telah dipaparkan oleh penulis, maka dapat diambil kesimpulan sebagai berikut :

1) Berdasarkan UU ITE, pemilik akun Instagram atau pembuat dapat memepertanggung jawabkan perbuatanya apabila memenuhi unsur sebagai berikut anatara lain. Unsur kesalahan: Dengan Sengaja, unsur melawan hukum: Tanpa Hak, unsur perbuatan: Mendistribusikan, Menstransmisikan, Membuat Dapat Diaksesnya. Unsur objek: Informasi Elektronik Dan/Atau Dokumen Elektronik Yang Memiliki Muatan Yang Melanggar Kesusilaan.

2) Sanksi terhadap pelaku tindak pidana cyberporn (pornografi) telah diatur dalam KUHP, UUP, dan UU ITE. Dalam UU ITE diancam pidana penjara paling lama 6 (enam) tahun dan/atau denda paling banyak Rp. 1.000.000.000,00 (satu miliar rupiah). Namun, ketentuan dalam UU ITE mengenai tindak pidana pornografi mengandung kekurangan dan kelemahan, antara lain perumusan melanggar kesusilaan yang bersifat abstrak dan multitafsir, perumusan beberapa istilah yang tidak mencakup aktifitas pornografi , perumusan tindak pidananya tidak secara eksplisit atau mengatur khusus mengenai cyberporn.

\subsection{Saran}

Berpedoman pada pembahasan yang telah dipaparkan diatas, ada beberapa saran yang perlu dikemukakan antara lain :
1) Perlu adanya suatu produk baru Perundang-Undangan yang khusus mengatur cyberporn yaitu pornografi di internet maupun di media sosial karena pasal 27 ayat (1) yang ada pada UU ITE masih sangat lemah. sehingga si pembuat dapat mempertanggungjawabkan perbuatannya.

2) Perlu adanya pembatasan yang jelas dalam hal pemberian definisi dan batasan yang jelas mengenai pornografi, khususnya dalam hal pembahasan pada UU ITE agar dalam menentukan sanksi pidananya tidak terjadi perbedaan penfsiran atau multitafsir. Misalnya dalam pasal 27 ayat (1) UU ITE, frasa "yang memiliki muatan yang melanggar kesusilaan" diganti menjadi frasa "yang memiliki muatan pornografi". Mengingat urgensi pornografi yang semakin membahayakan untuk kalangan remaja.

\section{DAFTAR PUSTAKA}

\section{Literatur}

Arief, Barda Nawawi, Tindak Pidana Mayantara, Raja Grafindo Persada, Jakarta, 2006.

Budhijanto, Danrivanto, Revolusi Cyberlaw Indonesia, Pembaruan dan Revisi UU ITE, Cet. 1, PT. Refika Aditama, Bandung, 2017.

Chazawi, Adami, Tindak Pidana Pornografi, Bayumedia Publishing, Malang, 2013

Chazawi, Adami, Tindak Pidana Pornografi, Sinar Garfika, Jakarta, 2016.

Chazawi, Adami Dan Ardi Ferdian, Tindak Pidana Informasi \& Transaksi Elektronik, Cet. 1, Edisi Revisi, Media Nusa Creative, Malang, 2015 
Djubaedah, Neng, Pornografi dan Pornoaksi Ditinjau dari Hukum Islam, Kencana, Jakarta, 2003.

Kamus Hukum, Cet. VIII, Cita Umbara, Bandung 2016.

Kamus Besar Bahasa Indonesia Pusat

Bahasa, Ed. 4, Gramedia Pustaka Utama, Jakarta, 2008

Huda, Chairul, Dari 'Tiada Pidana Tanpa Kesalahan' Menuju Kepada 'Tiada Pertanggungjawaban Pidana Tanpa Kesalahan', Prenadamedia Group, Cet. 6, Jakarta, 2015,

Marpaung, Leden, Asas, Teori, Praktik Hukum Pidana, Sinar Grafika, Cet. 9, Jakarta, 2017.

Mansur, Dikdik M. Arief dan Elistaris Gultom, Cyber Law, Aspek Hukum Teknologi Informasi, Rafika Aditama, Cet.

2, Bandung, 2009.

Marlina, Hukum Penitensier, Cet. 1, Refika Aditama, Bandung, 2011.

Marzuki, Peter Mahmud, Penelitian Hukum, prenadamedia group, Jakarta,2016.

Moeljatno, Asas-Asas Hukum Pidana, Rineka Cipta, Cet. 8, Jakarta, 2008.

Nasrullah, Rulli, Teori Dan Riset Media Siber (Cybermedia), Prenadamedia Group, jakarta, 2016.

Remmelink, Jan, Hukum Pidana Komentar Atas Pasal-Pasal Terpenting Dari KUHP Belanda dan Padananya Dalam KUHP Indonesia, Gramedia Pustaka Utama, Jakarta, 2003.

Sholehuddin, Sistem Sanksi Dalam Hukum Pidana, Ed. 1-3, Raja Grafindo Persada, Jakarta, 2007.
Rusianto, Agus, Tindak Pidana \& pertanggung jawaban Pidana. Jakarta: Prenadamedia group, 2016.

Soekanto, Soejono, Kegunaan Sosiologi Hukum Bagi Kalangan Hukum, Alumni, Bandung, 1976.

Siahaan, Monang, pembaruan Hukum Pidana Indonesia, PT. Grasindo, jakarta, 2016.

\section{Perundang-Undangan}

Undang-Undang Dasar Negara Republik Indonesia Tahun 1945.

Kitab Undang-Undang Hukum Pidana.

Kitab Undang-Undang Hukum Acara Pidana.

Undang-Undang Republik Indonesia Nomor 44 Tahun 2008 Tentang Pornografi

Undang-Undang Republik Indonesia Nomor 19 Tahun 2016 Tentang Perubahan Atas Undang-Undang Nomor 11 Tahun 2008 Tentang Informasi Dan Transaksi Elektronik.

\section{Karya Ilmiah}

Zainal Abdul Fattah, 'Perbandingan Konten Yang Dikecualikan Dalam Tindak Pidana Kesusilaan', Karya Ilmiah, Badan Pembinaan Hukum Nasional Kementerian Hukum Dan Ham RI, 2010.

\section{Jurnal Hukum}

Bambang Sudjito, et al, 'Tindak Pidana Pornografi dalam Era Siber di Indonesia', Wacana, Vol. 19, No. 2, 2016.

Dewi Bunga, 'Penanggulangan Pornografi Dalam Mewujudkan Manusia Pancasila', Jurnal Konstitusi, Vol. 8, No. 4, 2007.

Eka Nugraha Putra, 'Kejahatan Tanpa Korban Dalam Kejahatan Cyberporn', Jurnal Cakrwala Hukum, vol. 6, No. 1, 2015. 
Eliasta Ketaren, 'Cybercrime, Cyber Space, Dan Cyber Law', Jurnal Times, Vol. V, No. 2, 2016.

Enik Isnaini,'Penanggulangan Tindak Pidana

Pornografi Dalam Media Internet', Jurnal Independent, Vol. 2, No. 2.

Novita, 'Budaya Hukum Cyberporn Di Kota Semarang', Pandecta, Vol. 7, No. 2, 2012. Wahyu Agus Winarno, 'Sebuah Kajian Pada Undang-Undang Informasi Dan Transaksi Elektronik (UU ITE)', JEAM, Vol. X, No. 1, 2011.

\section{Media Daring}

Wikipedia ensiklopedia bebas, https://id.wikipedia.org/wiki/Instagram
, Diakses pada tanggal 20 Februari 2018.

Wikipedia ensiklopedia bebas, https://id.wikipedia.org/wiki/Google_Pl ay diakses pada tanggal 26 Juli 2018.

Admin, "Penelitian Hukum Normatif", http://www.informasi-

pendidikan.com/2013/08/penelitian-

hukum-normatif.html, diunggah 28 agustus 2017, dikunjungi pada tanggal 16 maret 2018.

Saiful anam dan partners, "Pendekatan Perundang-Undangan (Statue Approach) Dalam Penelitian Hukum", http://www.saplaw.top/tag/pendekatanhukum/, diunggah 28 desember 2017 